\title{
PERAN DUNIA USAHA DAN DUNIA INDUSTRI DALAM PENYELENGGARAAN SMK BERBASIS KEARIFAN LOKAL DI KOTA MATARAM
}

\author{
Indriaturrahmi \\ PTK PPs Universitas Negeri Yogyakarta \\ indriitu.indriaturrahmi@yahoo.com \\ Sudiyatno \\ Fakultas Teknik Univesitas Negero Yogyakarta \\ sudiyatno@uny.ac.id
}

\begin{abstract}
Abstrak
Penelitian ini bertujuan untuk mengetahui: (1) peran DUDI dalam mendorong produk kebijakan pendidikan Pemda Kota Mataram dalam mengembangkan SMK berbasis kearifan lokal; (2) implementasi penyelenggaraan kebijakan pendidikan SMK yang sesuai dengan kearifan lokal; dan (3) peran DUDI dalam pengembangan SMK. Informan kunci pada penelitian adalah Kepala Dinas Dikmen sub-bagian kepala seksi kurikulum, Kepala Sekolah, Wakasek Humas Industri, Pembimbing Industri, dan Siswa. Teknik pengumpulan data melalui observasi, wawancara mendalam dan dokumentasi. Teknik analisis data meliputi reduksi data, penyajian data dan penarikan kesimpulan. Hasil penelitian ini menunjukkan bahwa: (1) peran DUDI dalam mendorong kebijakan Pemda terkait pengembangan SMK berbasis kearifan lokal belum memadai; (2) implementasi kebijakan Pemda, antara lain: (a) monitoring dan evaluasi, (b) menyediakan unit gedung baru, (c) membuka kompetensi keahlian baru, (d) pemberian dana, (e) mengadakan Gebyar SMK se-Kota Mataram; dan (3) peran DUDI dalam pengembangan SMK antara lain: (a) penyelenggaraan prakerin siswa berjalan dengan baik. b) industri sebagai tempat pemagangan guru, c) industri terlibat dalam uji kompetensi siswa tingkat akhir dan tempat menyalurkan lulusan, d) belum ada kerja sama terkait penyediaan sarana dan prasarana, dan e) pengembangan kurikulum dalam bentuk workshop kurikulum.
\end{abstract}

Kata kunci: peran DUDI, penyelenggaraan SMK, kearifan lokal

\section{THE ROLE OF BUSINESS AND INDUSTRY IN THE IMPLEMENTATION OF VOCATIONAL HIGH SCHOOL (VHS) BASED ON LOCAL WISDOM IN THE CITY OF MATARAM}

\begin{abstract}
This research aims to know: (1) the role of business and industry in encouraging the product education policy of the local government in Mataram City for developing vocaational high school (VHS) based on local wisdom; (2) the implementation of VHS education policy with an appropriate local wisdom; and (3) the role of business and industry in developing VHS. The key informants in this research were the Head of Secondary Education Curriculum Sub-section, Principal, Vice Principal of Industry Public Relations, Industry Counsellors, and students. The data were collected by observation, in-depth interviews and documentation. The data analysis technique included data reduction, data display and conclusion drawing. The results showed that: (1) the role of business and industry in encouraging the regional government policy related to VHS development based on local wisdom had not been adequate; (2) the implementation of regional government policy were among others: (a) monitoring and evaluation, (b) providing a new building unit, (c) opening new expertise competencies, (d) providing funds, (e) conducting Gebyar SMK in the city of Mataram; and (3) the roles of business and industry in the development of VHS were among others: (a) the implementation of the students' industrial practice ran well, (b) the industry as the place for teachers' apprenticeship, (c) the industry was involved in students' competency test at the end of the students' study and as an institute which would recruit the graduates, d) there had not been any cooperation related to the provision of facilities and infrastructure, and e) curriculum development in the form of a curriculum workshop.
\end{abstract}

Keywords: the role of business and industry, implementation of VHS, local wisdom 


\section{PENDAHULUAN}

Sekolah Menengah Kejuruan (SMK) merupakan lembaga pendidikan formal di bawah Direktorat Pembinaan SMK (DitpSMK) yang menyiapkan lulusannya untuk bekerja dengan bekal pengetahuan, keterampilan dan sikap kerja dalam bidang tertentu yang sesuai dengan kebutuhan Dunia Usaha dan Dunia Industri (DUDI), serta diharapkan dapat berwirausaha. Hal ini tercantum dalam UUSPN Pasal 18 dan penjelasan Pasal 15 yang mengatur Pendidikan Menengah Kejuruan, sejalan dengan Rencana Pembangunan Jangka Panjang Departemen Pendidikan Nasional (RPJP Depdiknas) Tahun 2005-2025 SMK yang akan menjadi icon dalam perkembangan dunia pendidikan menengah di negera kita. Secara bertahap rasio jumlah lembaga pendidikan kejuruan (SMK) dibanding pendidikan umum SMA akan berubah secara signifikan. Menurut Sutrisno (2006,p.3) pendidikan kejuruan pada dasarnya diselenggarakan untuk mempersiapkan tenaga kerja terampil tingkat menengah untuk mendukung pembangunan sektor perekonomian bangsa. Secara spesifik pendidikan kejuruan diselenggarakan untuk (1) melakukan transformasi status siswa, dari manusia "beban" menjadi manusia "aset". (2) mempersiapkan sumber daya manusia yang memiliki keunggulan komparatif (comparative advantage) dan kompetitif (competitive advantage) bagi pembangunan sektor industri dan sektor-sektor ekonomi lainnya di indonesia. (3) memberi bekal bagi siswa/tamatan untuk berkembang secara berkelanjutan. Depdiknas tentang kebijakan untuk pembalikan rasio peserta didik SMK di banding SMA dari 30:70 pada tahun 2004 menjadi 70:30 pada tahun 2015 (Depdiknas,2006b). Kebijakan ini ditujukan agar keluaran pendidikan kejuruan dapat lebih berorientasi pada pemenuhan dunia kerja serta kebutuhan dunia usaha dan dunia indusri (DUDI).

Beberapa strategi yang telah dilakukan dalam menjawab tantangan tersebut, Direktorat Pembinaan SMK akan menyiapkan lulusan agar siap pakai. Strategi tersebut di antaranya adalah: merubah dan memperbaiki kurikulum yang disesuaikan dengan kebutuhan dunia kerja dan industri, pemenuhan pengajar dalam waktu pendek, pemenuhan peralatan murah, dan implementasi industri perdagangan dan jasa Indonesia berbasis Kemitraan SMK- industri. Usaha tersebut dilakukan untuk meningkatkan penyelenggaraan proses pembelajaran agar lebih efektif dan efisien (Roadmap Pengembangan SMK 2010-2014).

Permasalahan yang muncul dari usaha tersebut adalah menuntut SMK harus bisa menyesuaikan dengan DUDI, namun SMK juga menuntut biaya investasi yang besar, karena SMK membutuhkan fasilitas praktik berupa gedung, mesin-mesin, peralatan dan fasilitas pendukung praktek lainnya serta biaya operasional yang tinggi. Upaya yang dilakukan untuk meningkatkan jumlah siswa SMK dalam mencapai perbandingan $70 \%$ siswa SMK dan 30\% siswa SMA di antaranya dilakukan melalui kemitraan atau kerja sama dengan industri, berupaya terus menerus meningkatkan jumlah siswa SMK di samping juga terus meningkatkan mutu SMK. Pendapat tersebut menekankan bahwa industri mampu membantu meningkatkan mutu siswa dan sekolah. Hal ini sesuai dengan prinsip pendidikan yang dijelaskan oleh Charles Prosser (1925) dalam Djojonegoro (1998,p.38) ada 16 prinsip yang dapat dikemukan dalam pendidikan kejuruan, dan di antaranya yang terkait dengan peran industri ada tiga prinsip. Pendidikan kejuruan akan efektif jika (1) tugas-tugas latihan dilakukan dengan cara, alat, dan mesin yang sama seperti yang ditetapkan di tempat kerja dan (2) melatih seseorang dalam kebiasaan berpikir, dan bekerja seperti yang diperlukan dalam pekerjaan itu sendiri. (3) pendidikan kejuruan akan efisien jika lingkungan tempat siswa dilatih, merupakan replika lingkungan tempat nanti ia akan bekerja. Efisiensi ini diperoleh karena bagi industri tidak perlu menyelenggarakan pusat-pusat diklat lagi. Untuk memenuhi ketiga prinsip ini, sekolah kejuruan memerlukan biaya yang sangat besar, apalagi bila ingin memenuhi keseluruhan prinsip dari Prosser (Pardjono, 2011,p.2).

Merealisasikan kondisi tersebut sangat sulit karena dana yang diberikan Pemerintah untuk pengembangan fasilitas praktik sangat terbatas. Hal ini menyebabkan adanya kesenjangan antara supply dan demand antara SMK dan industri. Untuk menanggulangi masalah tersebut ditempuh dengan cara menjalin kerja sama dengan DUDI. Kerja sama dengan DUDI dapat meningkatkan efisensi dan efektivitas penyelenggaraan SMK. Kerja sama SMK dan DUDI dapat mendukung tercapainya orientasi pendidikan kejuruan di SMK. 
Menurut Djojonegoro (1998, p.35), orientasi pendidikan kejuruan membawa konsekuensi bahwa pendidikan kejuruan harus selalu dekat dengan dunia kerja. Kedekatan tersebut dalam artian bahwa perencanaan dan penyelenggaraan pendidikan kejuruan harus sesuai dengan kebutuhan dunia kerja, mulai dari kurikulum, hingga penyaluran lulusan. Oleh karena itu, salah satu faktor penentu keberhasilan penyelenggaraan pendidikan kejuruan adalah kerja sama atau kemitraan dengan DUDI selaku penyedia lapangan kerja

Kualitas lulusan SMK turut secara langsung merefleksikan kualitas tenaga kerja Indonesia, oleh karena itu kualitas tenaga kerja harus dibangun untuk meningkatkan keunggulan kompetitif SDM yang tangguh dalam menghadapi persaingan di era bebas ASEAN. Dalam hal ini SMK sebagai pendidikan kejuruan harus menyiapkan peserta didik atau SDM yang memiliki kemampuan kerja sebagai tenaga kerja menengah sesuai dengan tuntutan dunia usaha dan dunia industri. Berdasarkan data BPS Provinsi Nusa Tenggara Barat (NTB), jumlah pengangguran di Provinsi NTB pada Februari 2014 bertambah sebanyak tiga ribu lebih jika dibanding tahun sebelumnya. Jumlah angkatan kerja pada Februari 2014 sebanyak 2,3 juta orang lebih. Angka itu bertambah sebanyak 189 ribu orang dibanding keadaan Agustus 2013 yang berjumlah 2,1 juta orang lebih. Menurut jenjang pendidikan, tingkat pengangguran terbuka (TPT) tertinggi masih mendominasi oleh TPT Sekolah Menengah Kejuruan (SMK) sebesar $12,91 \%$ dan TPT Sekolah Menengah Atas Mencapai $11,24 \%$. Ini mengindikasikan bahwa, lulusan SMK masih banyak yang tidak terserap dan menjadi pengangguran. Banyaknya siswa SMK yang tidak terserap pada dunia kerja, merupakan refleksi dari kualitas pendidikan kejuruan.

Tingginya jumlah pengangguran lulusan SMK, menimbulkan spekulasi tentang penyebab angka penganguran selama ini terus berkembang dan selalu dikaitkan dengan dunia pendidikan selaku pencetak lulusan yang akan menjadi angkatan kerja (Tim Penyelaras Pendidikan dengan Dunia Kerja, 2010, p.3). SMK yang bertujuan untuk menyiapkan tenaga kerja tingkat menengah, yang lulusannya harus siap memasuki lapangan kerja diperlukan untuk mengembangkan perekonomian daerah, sehingga penyelenggaraan SMK rele- van dengan kebutuhan dunia kerja yang ada di daerah. Kaitan dengan penyelenggaraan SMK yang ada di daerah, sesuai dengan prinsip desentralisasi, yaitu perubahan manajemen terpusat ke pola manajemen mandiri (Djojonegoro,1988,p.76). Prinsip desentralisasi ini, dimaksudkan untuk merubah pola manajemen lama yang pelaksanaan pendidikan kejuruan di atur oleh pemerintah pusat, sehingga menyebabkan program pendidkan kejuruan tidak relevan dengan kebutuhan dunia kerja yang di daerah. Dengan prinsip desentralisasi ini, pemerintah daerah dapat merencanakan dan menyelenggarakan pendidikan kejuruan sesuai dengan potensi dan sumber daya yang dimilliki oleh daerah tersebut.

Dalam rangka pengembangan otonomi daerah, Wayong (1979,p.16) mengemukakan bahwa otonomi daerah adalah kebebasan untuk memelihara dan memajukan kepentingan khusus daerah, dengan keuangan sendiri, menentukan hukum sendiri, dan pemerintah sendiri. Syarifuddin (1991,p.23) mengemukakan bahwa istilah otonomi mempunyai makna kebebasan dan kemandirian, tetapi bukan kemerdekaan. Kebebasan yang terbatas atau kemandirian itu adalah wujud pemberian kesempatan yang harus dipertanggungjawabkan. Sarundajang (2001, p.34) menulis bahwa pada hakikatnya otonomi daerah adalah: (1) hak mengurus rumah tangga sendiri bagi suatu daerah otonom; (2) dalam kebebasan menjalankan hak mengurus dan mengatur rumah tangga sendiri, daerah tidak dapat menjalankan hak dan wewenang otonominya itu di luar batas-batas wilayah daerahnya; (3) daerah tidak boleh mencampuri hak mengatur dan mengurus rumah tangga daerah lain sesuai dengan wewenang pangkal dan urusan yang diserahkan kepadaya; (4) otonomi tidak membawahi otonomi daerah lain, hak mengatur dan mengurus rumah tangga sendiri tidak merupakan subordinasi hak mengatur dan mengurus rumah tangga daerah lain. Menurut UU No.32 Tahun 2004, tentang pemahaman pemerintah daerah pada pasal 1 ayat (5) menyebutkan bahwa otonomi daerah adalah hak, wewenang dan kewajiban daerah otonom untuk mengatur dan mengurus sendiri urusan pemerintah dan kepentingan masyarakat setempat sesuai dengan peraturan perundangundangan. Daerah otonom dimaksudkan adalah kesatuan masyarakat hukum yang mempunyai dan mengurus urusan batas wilayah 
yang berwenang mengatur dan mengurus urusan pemerintah dan kepentingan masyarakat setempat menurut prakarsa sendiri berdasarkan aspirasi masyarakat dalam sistem Negara Kesatuan Republik Indonesia (NKRI). Dapat dikatakan otonomi daerah adalah hak kemandirian setiap daerah dalam mengelola daerahnya, tanpa campur tangan dari pihak lain, akan tetapi tetap merujuk pada pemerintah pusat.

Desentralisasi pendidikan diartikan sebagai pelimpahan wewenang yang lebih luas (Jalal dkk, 2001, pp.125-126). Desentralisasi tidak saja mendorong pemerintah nasional membangun manajemen pendidikan yang terdesentralisasi, melainkan juga pendorong bagi daerah untuk mengembankan manajemen pendidikan yang bermutu. Dengan otonomi dan desentralisasi diharapkan semua komponen daerah lebih terpacu memberdayakan diri, mengembangkan mutu "kompetensi" sumber daya manusia, menumbuhkan prakarsa dan kreativitas, meningkatkan peran serta masyarakat, termasuk dalam meningkatkan sumber dana dan dalam penyelenggaraan pendidikan (Usman, 2005,p.233). Dengan adanya desentralisasi setiap daerah dapat mengembangkan keunggulan daerahnya, agar dapat membangun SDM yang unggul.

Setiap daerah di Indonesia mempunyai sektor unggulan yang berbeda-beda sesuai dengan potensi daerah yang dimiliki. Pemetaan sektor unggulan untuk setiap Kabupaten/Kota berdasarkan PDRB dan identifikasi bidang keahlian SMK untuk mengetahui apakah sudah sesuai dengan sektor unggulan yang diperkirakan, dan melakukan proyeksi pertumbuhan sektor unggulan dan penyerapan lulusan SMK di Kabupaten/Kota yang bersangkutan (Tim Penyelaras Pendidikan dan Dunia Kerja, 2010,p.22). Daerah memiliki kewenangan untuk menentukan kebijakan pengembangan program pendidikan SMK yang sesuai dengan konteks daerah, sehingga lulusan SMK dapat bekerja sesuai dengan kebutuhan tenaga kerja dan perekonomian lokal daerah. Menurut Wagiran (2010,p.597) faktor yang mempertemukan program pendidikan SMK dengan perekonomian daerah adalah produktivitas tenaga kerja. SMK mengemban misi mempersiapkan lulusannya dengan keterampilan dan kecakapan tertentu agar menjadi tenaga kerja yang lebih tinggi produktivitasnya. Sementara itu, daerah berkepentingan dan berusaha untuk memperoleh tenaga kerja dengan produktivitas tinggi (lulusan SMK) yang diperlukan untuk mengembangkan dan mendayagunakan potensi perekonomian daerah. Pendidikan berbasis kearifan lokal adalah segala sesuatu yang menjadi ciri khas kedaerahan yang mencakup aspek ekonomi, budaya, teknologi informasi, komunikasi, ekologi dan lain sebagainya (Asmani, 2012, p29). Kearifan lokal harus dikembangkan berdasarkan potensi daerah. Potensi daerah merupakan potensi sumber daya spesifik yang dimiliki oleh suatu daerah.

Dalam meningkatkan kualitas lulusan SMK perlu adanya program penyelarasan antara SMK dengan DUDI. Dalam program penyelarasan yang dimaksud adalah penyelarasan dari supply side dan demand side. Penyelarasan dari supply side merupakan upaya penyesuaian lulusan yang dihasilkan oleh dunia pendidikan dengan kebutuhan dunia kerja yang direpresentsikan melalui tingkat penyerapan tenaga kerja sedangkan penyelarasan dari demand side direpresentasikan melalui tingkat pemenuhan permintaan dunia kerja (Tim Penyelaras Pendidikan dengan Dunia Kerja, 2010, p.15). Salah satu kebijakan pengembangan pendidikan kejuruan yang cukup menonjol adalah pada masa Kabinet Pembangunan VI, yaitu kebijakan "link and match". Kebijakan ini mengimplikasikan wawasan sumber daya, mutu, keunggulan, profesionalisme dan ekonomi dalam pendidikan kejuruan, sehingga menghasilkan suatu model pendidikan kejuruan yang kita kenal dengan pendidikan sistem ganda (PSG), sebagai bentuk penyelenggaraan pendidikan kejuruan yang memadukan secara sistematik dan sinkron program pendidikan di sekolah dan program belajar melalui kegiatan bekerja langsung pada bidang pekerjaan yang relevan, terarah untuk mencapai penguasaan kemampuan tertentu.

Pakpaham menyebutkan pendidikan sistem ganda (PSG) merupakan model penyelenggaraan pendidikan kejuruan yang perencanaan dan pelaksanaan pendidikan diwujudkan melalui kerja sama atau kemitraan antara dunia kerja dengan sekolah, dan penyelenggaraan berlangsung sebagian di sekolah dan sebagian lagi di DUDI (Anwar, 2001,p.3). Pelaksanaan PSG pada SMK memiliki karakteristik yang berbeda. Karakteristik itu antara lain: (a) institusi pasangan dan (b) program 
Pendidikan dan Pelatihan Bersama yang terdiri dari (1) Standar Kompetensi/Keahlian Tamatan; (2) Standar Pendidikan dan Pelatihan (materi, waktu, pola pelaksanaan); (3) Penilaian dan Sertifikasi; (4) Kelembagaan dan (5) Nilai Tambah dan insentif (Muliati, 2008, p.10). Pada perkembangan saat ini, pelaksanaan PSG lebih dikenal dengan praktik indusrti (PI) atau biasa disebut dengan praktik kerja industri (Prakerin). Tujuan prakerin salah satunya adalah untuk memberikan pengalaman serta mempraktikkan ilmu dan keterampilan yang sudah diperoleh di sekolah dengan kondisi nyata di dunia kerja (Priyatama, 2013, p.157). DUDI sebagai mitra kerja sama dengan SMK, menitipkan siswa untuk melaksanakan prakerin. Untuk mengimplementasikan ilmu yang didapatkan di bangku sekolah pada dunia kerja. DUDI sebagai mitra kerja sama dengan SMK, diharapkan selain sebagai tempat prakerin siswa, dapat juga melaksanakan kerja sama lain. Kerja sama antara sekolah dengan DUDI, dapat berupa penyaluran lulusan, sarana dan prasarana, relevansi kurikulum, serta kerja sama lain yang tentunya dapat menguntungkan pihak DUDI dan dapat mengembangkan SMK. Hasil penelitian yang telah dilakukan Qurrotu (2009), dalam jurnal penataan ruang, dengan judul "Konsep Pengembangan Sekolah Menengah Kejuruan (SMK) Berbasis Industri di Kabupaten Sidoardjo". Hasil penelitian ini adalah konsep pengembangan SMK berbasis industri di Kabupaten Sidoardjo yaitu, konsep pengembangan SMK yang "sesuai" dan "tidak sesuai" dapat ditingkatkan dengan memperhatikan faktor-faktor pendukung kesesuain bidang keahlian SMK dengan potensi industri di Kabupaten Sidoardko. Konsep pengembangan tersebut dapat melalui efisiensi dan efektivitas manajemen sekolah, peningkatan kompetensi tenaga pengajar, peningkatan hubungan kerja sama dengan industri dan re-engineering program keahlian SMK jurusan teknologi industri.

Beberapa permasalahan yang dihadapi dalam SMK yang ada di kota Mataram, antara lain masih tingginya angka pengangguran yang dihasilkan oleh lulusan SMK, menurut data BPS Februari 2014, memberikan pertanyaan besar tentang penyebab tingginya angka pengangguran, yang dikaitkan dengan pendidikan kejuruan yang menghasilkan SDM tingkat menengah yang memiliki keteram- pilan dan kemampuan untuk bekerja atau berwirausaha sesuai dengan kompetensi keahlian yang ditekuni. Dengan diberlakukannya otonomi daerah, maka setiap daerah berhak mengelola penyelenggaraan pendidikannya termasuk SMK penyelenggaraan kompetensi keahlian pada SMK harusnya disesuaikan dengan kearifan lokal, harapannya agar lulusan pendidikan tersebut relevan dengan kebutuhan pasar kerja di daerahnya. Permasalahan lain yang dihadapi SMK yang bersama-sama dengan industri, haruslah berupaya membangun kompetensi unggulan daerah, di samping itu dalam penyelenggaraan SMK Pemerintah harus memperhatikan kebutuhan dan kearifan lokal daerah. Dalam penyelenggaraan SMK diperlukan adanya kolaborasi antara sekolah dengan DUDI selaku penyerap tenaga kerja. Dengan adanya program "link and match" melalui kerja sama antara SMK dan DUDI yang peran DUDI dalam SMK erat kaitannya dengan Program studi apa yang diperlukan, kurikulum dan kompetensi seperti apa yang diinginkan oleh DUDI. Melalui penelitian ini diharapakan peneliti dapat mengungkap peran DUDI terhadap SMK yang berbasis kearifan lokal, dalam penyelenggaraan SMK yang relevan dengan kearfian dan kebutuhan daerah, serta dapat mendorong pertumbuhan ekonomi lokal dan pembangunan daerah.

Pertanyaan penelitian yang harus mendapatkan jawaban dalam penelitian ini antara lain: (1) bagaimana peran DUDI dalam mendorong produk kebijakan pendidikan, dalam hal ini program atau peraturan dari pemerintah daerah (Pemda) Kota Mataram dalam mengembangkan SMK berbasis kearifan lokal?; (2) bagaimana implementasi penyelenggaraan kebijakan pendidikan SMK di Kota Mataram yang sesuai dengan kearifan lokal daerah?; (3) Bagaimana peran DUDI dalam pengembangan SMK di Kota Mataram?.

\section{METODE PENELITIAN}

Penelitian ini merupakan penelitian kualitafif yang dilakukan dengan cara mengumpulkan data, menyajikan informasi yang akurat dan objek. Data dan informasi diperoleh untuk mendeskripsikan hasil dari penelitian ini. Penelitian ini dilakukan di SMK Negeri 5 Mataram pada Kompetensi Keahlian Kria Logam, SMK Pertanian Pembangunan (PP) Negeri Mataram, pada Kompetensi Ke- 
ahlian Agribisnis Tanaman Pangan dan Hortikultura, Kompetensi Keahlian Agribisnis Teknik Ruminansia dan Kompetensi Keahlian Agribisnis Perikanan.

Unit analisis dilakukan pada informan yang terkait dengan penyelengaraan SMK berbasis kearifan lokal daerah di Kota Mataram. Dalam penelitian ini yang menjadi sumber infomasi adalah kepala Dinas Dikpora Kota Mataram khsususnya Dinas Pendidikan Menengah. Kepala Sekolah, Wakasek Humas Industri, dan siswa di SMK 5 Mataram dan SMK PP N Mataram, serta pembimbing industri pada DUDI tempat prakerin siswa.

Bentuk data penelitian kualitatif ialah kata-kata dan tindakan, selebihnya adalah tambahan seperti dokumen dan lain-lain. Bentuk data atau responden penelitian ini adalah Kepala Sekolah, Wakasek Humas Industri, Siswa, Pembimbing Industri dan Kepala Dinas Dikmen Sub-bagian Kepala Seksi kurikulum. Pemilihan informan/sumber informasi yang digunakan oleh peneliti adalah Teknik purposive sample, yang bertujuan dapat memberikan pertimbangan untuk memilih informan yang memenuhi kriteria dalam memberikan informasi yang akurat. Pemilihan informan merupakan hal yang sangat utama sehingga harus dilakukan secara cermat, maka peneliti memutuskan informan pertama atau informan kunci. Data awal sejumlah responden berdasarkan sumber informan yang telah dipilih melalui wawancara terus bergulir sampai mengalami titik jenuh (Snowball Sampling).

Pengumpulan data dilakukan pada kondisi yang alamiah (natural setting), sumber data primer, dan teknik pengumpulan melalui observasi, wawancara mendalam dan dokumentasi. Metode analisis data yang digunakan meliputi reduksi data, penyajian data dan penarikan kesimpulan.

\section{HASIL PENELITIAN DAN PEMBAHASAN}

\section{Kerja Sama PT. BISI International Tbk dengan SMK PP N Mataram}

Prakerin merupakan salah satu bentuk kerja sama antara PT. BISI dan SMK PP N Mataram yang rutin dilaksanakan hampir setiap tahun. Bentuk kerja sama lain yang dilakukan adalah pengembangan kurikulum, dalam bentuk workshop kurikulum dan sebagai asesor dalam uji kompetensi kerja siswa. Siswa melaksanakan prakerin pada PT. BISI selama 2-3 bulan. Hal-hal yang didapatkan siswa setelah melaksanakan prakerin, antara lain: banyak mendapatkan pengalaman baru terkait dunia kerja, meningkatkan skill kompetensi keahlian yang dimilliki, serta dapat membentuk karakter siswa menjadi lebih disiplin. Pada PT.BISI diajarkan untuk disiplin dan tekun selama kegiatan prakerin berlangsung. Di samping itu, kemauan untuk belajar sangat diperlukan, sehingga siswa setelah prakerin merasa lebih banyak mendapatkan pengetahuan baru.

\section{Kerja Sama Balai Inseminasi Buatan (BIB) Banyumulek dengan SMK PP N Mataram}

Prakerin merupakan salah satu bentuk kerja sama antara BIB dan SMK PP N Mataram yang rutin dilaksanakan hampir setiap tahun. Bentuk kerja sama lain yang dilakukan adalah pengembangan kurikulum, dalam bentuk workshop kurikulum dan sebagai asesor dalam uji kompetensi kerja siswa. Siswa melaksanakan prakerin pada BIB selama 2-3 bulan. Siswa yang telah mengikuti prakerin, merasakan banyak manfaat. Materi pelajaran yang dirasa kurang didapatkan di sekolah, didapatkan lebih banyak saat mengikuti prakerin. Contohnya, dari cara pemeliharaan sapi yang dirasa belum cukup dari materi yang diberikan di sekolah, menjadi lebih banyak saat prakerin di BIB. Setiap mendapatkan kesulitan, tak jarang siswa dibantu ataupun mengadakan diskusi atau sharing dengan pembimbing industri yang ada BIB. Kegiatan rutin yang dilaksanakan hampir setiap hari yang harus diikuti oleh siswa, menjadi bekal siswa dalam meningkatkan kompetensi keahlian yang dimiliki. Kedisiplinan merupakan modal utama dalam melaksanakan kegiatan prakerin di BIB, sehingga siswa memang dituntut untuk selalu disiplin saat mengerjakan pekerjaan mereka.

\section{Kerja Sama Balai Budidaya Laut (BBL) Gerupuk dengan SMK PP N Mataram}

Prakerin merupakan salah satu bentuk kerja sama antara BBL Gerupuk dan SMK PP $\mathrm{N}$ Mataram yang rutin dilaksanakan hampir setiap tahun. Bentuk kerja sama lain yang dilakukan adalah pengembangan kurikulum, dalam bentuk workshop kurikulum dan sebagai 
asesor dalam uji kompetensi kerja siswa. Siswa melaksanakan prakerin pada BBL Gerupuk selama 2-3 bulan. Setelah mengikuti prakerin siswa lebih merasa percaya diri, karena telah mendapatkan ilmu pengetahuan dalam meningkatkan kemampuan pada kompetensi keahlian yang ditekuni. Saat prakerin siswa lebih banyak praktik daripada teori. Hal ini mengikuti kegiatan pekerjaan yang ada di BBL. Selain itu, siswa merasa lebih disiplin dan bertanggung jawab saat diberikan pekerjaan.

\section{Kerja Sama CV. Budi Silver dengan SMKN 5 Mataram}

Prakerin merupakan bentuk kerja sama antara CV. Budi Silver dan SMKN 5 Mataram. Selama prakerin kesesuaian antara materi yang didapatkan di sekolah dengan apa yang dikerjakan di industri hampir sama. Hanya saja yang dirasa kurang adalah praktik, di sekolah siswa sudah diberikan teori. Praktik di sekolah dinilai masih kurang. Jadi, saat melakasanakan kegiatan prakerin siswa benarbenar dituntut untuk bisa. Dalam mengikuti prakerin, siswa yang tadinya kurang memahami atau kurang paham dalam hal praktik menjadi bisa dan tahu apa yang harus dilakukan. Hal ini dikarenakan selama prakerin telah diberikan wadah dan alat serta kesempatan untuk bekerja.

\section{Peran DUDI dalam Mendorong Kebijakan Pemerintah Daerah (Pemda) untuk Pengembangan SMK Berbasis Kearifan Lokal}

Fungsi SMK yang disampikan dalam Renstra Dikjen Dikmen Tahun 2010-2014, SMK dalam mempersiapkan kebutuhan tenaga kerja yang diperlukan untuk mengembangkan perekonomian daerah mencakup dua dimensi. Pertama, berkaitan dengan fungsi program pendidikan SMK dalam memasok tenaga kerja terdidik dan terampil sesuai dengan kebutuhan lapangan kerja yang ada di daerah. Kedua, menyangkut fungsinya sebagai penghasil tenaga kerja terdidik, terlatih dan terampil yang akan menjadi sumber penggerak pengembangan perekonomian daerah.

Pendidikan berbasis keunggulan lokal sebagai pendidikan yang memanfaatkan keunggulan lokal, baik ekonomi, sosial, budaya dan sumber daya alam. Menurut Peraturan
Daerah (Perda) Provinsi NTB Nomor 4 Tahun 2015 tentang Penyelenggaraan Pendidikan dijelaskan pada BAB 1 Ketentuan Umum Pasal 1 (20), keunggulan lokal adalah aspek ekonomi, budaya, bahasa, teknologi, ekologi yang bermanfaat bagi pengembangan kompetensi peserta didik. Dalam penyelenggaraan pendidikan, khususnya pendidikan SMK kompetensi keahlian yang dikembangkan harus disesuaikan dengan tuntutan kebutuhan SDM diwilyah/daerah setempat baik untuk kebutuhan lokal wilayah maupun daerah lain secara regional. Menurut Surat Keputusan Mendiknas No.060 /u/ 2002 Bab.V Pasal 22 tentang Penambahan dan Perubahan Bidang/program Keahlian SMK, persyaratannya sebagai berikut: Hasil Studi Kelayakan, RIPS, Sumber Peserta Didik, Tenaga Kependidikan, Tenaga Nonkependidikan, Kurikulum, Sumber Pembiayaan, Sarana prasarana, Potensi lapangan kerja yang sesuai dengan tamatan SMK, Sekolah sejenis di wilayah, Dukungan DU/DI dan Masyarakat, Bidang/Program keahlian ada di spektrum pendidikan yang berlaku, Program keahlian yang diusulkan mempunyai SKKNI (Standar Kompetensi Keahlian Nasional Indonesia).

Peran DUDI dalam mendorong kebijakan pemerintah daerah (pemda) dalam pengembangan SMK berbasis kearifan lokal sampai saat ini belum memadai. Pemerintah dengan industri sejauh ini belum terlibat dalam pengembangan SMK, terutama SMK yang berbasis kearifan lokal. Kebijakan pemerintah dalam pengembangan SMK yang berbasis kearifan lokal pada Kota Mataram belum ada dalam bentuk kebijakan ataupun program. Kegiatan kerja sama antara sekolah dengan industri telah diberikan tanggung jawab sepenuhnya pada sekolah. Sekolah mengelola, bagaimana bentuk kerja sama, hubungan dan kegiatan yang dilaksanakan dengan DUDI yang ada, baik di Wilayah NTB maupun di luar daerah NTB. Pemda telah berusaha mengembangkan SMK yang berbasis potensi daerah dalam bentuk pembukaanpembukaan kompetensi keahlian yang disesuaikan dengan kebutuhan pasar kerja yang ada di daerah. Pembukaan kompetensi keahlian ini memang didasarkan atas petunjuk teknis dari DitpSMK, akan tetapi dalam hal implementasi di daerah. Pembukaan kompetensi kehalian tersebut disesuaikan dengan kebutuhan pasar kerja yang ada daerah. 
Dalam mengembangkan perekonomian daerah berdasarkan kearifan lokal, seharunya pembukaan kompetensi kehalian dikhususkan pada unggulan-unggulan daerah tersebut, agar lulusan SMK tersebut akan menjadi penggerak perkonomian daerah. Pemda dalam hal ini, Dinas Dikpora mendukung apa saja bentuk kegiatan, yang bertujuan untuk mengembangkan pendidikan yang berbasiskan kearifan lokal. Kota Mataram yang memiliki potensi daerah dalam bidang kerajinan EMP, telah membuka SMK kriya (SMKN 5 Mataram). Di samping itu, dibuka juga kompetensi kehalian Agrobisnis ternak ruminansia, tanaman hortikultura dan teknik perikanan pada SMK PP N Mataram, untuk mendukung program Pijar dari Pemerintah Daerah.

Beberapa program yang dilakukan Pemda dalam meningkatkan kualitas penyelenggaraan SMK yang ada di Kota Mataram, antara lain: (1) monitoring dan evaluasi, (2) unit sekolah baru (USB), (3) pembukaan program baru atau kompetensi keahlian baru, (4) bantuan dana BOS dan BOSDA, serta (5) gebyar SMK se-Kota Mataram.

\section{Implementasi Penyelenggaraan SMK Di Kota Mataram}

\section{Monitoring dan Evaluasi}

Monitoring dan evaluasi ini bertujuan untuk mendapatkan informasi yang digunakan untuk pengambilan keputusan. Hasil dari monitoring akan digunakan untuk memberikan binaan berupa masukan (umpan balik), bagi perbaikan pelaksanaan program. Hasil dari evaluasi dapat memberikan informasi yang dapat digunakan untuk memberikan masukan terhadap keseluruhan komponen. Penyelenggaraan Monitoring dan Evaluasi dilakukan pada sekolah dengan jadwal yang sudah ditentukan oleh Dinas Dikpora Kota Mataram yang dibantu oleh pengawas sekolah.

\section{Unit Sekolah Baru (USB)}

Dalam pelaksanaannya diwujudkan pembangunan ruang kelas baru (RKB) dan pembangunan unit gedung baru (UGB) bagi SMK. Pada tahun anggaran 2015, program bantuan Pembinaan SMK dialokasikan melalui dana pusat dan dana dekonsentrasi. Program bantuan pusat disampaikan kepada SMK dan institusi dalam bentuk uang atau barang/ jasa. Program dana dekonsentrasi dimanfaatkan untuk mendukung kegiatan pembinaan SMK secara swakelola oleh Dinas Pendidikan Provinsi. (Juknis Bantuan Pembanguan Unit Sekolah Baru dan Unit Kelas Baru, 2015). Dengan adanya pembanguan RKB dan UGB ini, diharapkan dapat meningkatkan mutu pendidikan, sehingga dapat memperlancar proses belajar mengajar terutama dalam penciptaan suasana dan efektifitas dan pengefektifan proses belajar mengajar.

\section{Pembukaan Program Baru atau Kompetensi Keahlian Baru}

Pembukaan kompetensi keahlian baru yang ada di SMK disesuaikan dengan kebutuhan pasar kerja industri yang ada di daerah. Dinas Pendidikan memiliki wewenang untuk membuka, memperbaharui atau menutup kompetensi keahlian yang ada di SMK. Tentunya hal ini didasarkan atas kebutuhan dunia ker-ja yang ada di daerah. Dalam membuka program baru tentunya ada koordinasi langsung dengan sekolah terkait, kebutuhan, guru dan sarana perasaran pendukung yang perlu untuk dipersiapkan.

\section{Bantuan Dana}

BOS SMK adalah program pemerintah berupa pemberian dana langsung ke Sekolah Menengah Kejuruan yang besaran dana bantuan yang diterima sekolah dihitung berdasarkan jumlah siswa masing-masing sekolah dikalikan dengan besarnya satuan dana bantuan. Dana BOS SMK di gunakan untuk membantu sekolah memenuhi biaya operasional sekolah non personalia. (Juknis BOS SMK, 2015). BOSDA (BOS Daerah) merupakan pemberian dana dari pemerintah daerah terhadap SMK Negeri yang ada di wilayah tersebut. Dalam hal ini, Dinas Dikpora Kota Mataram memberikan melalui dana APBD daerah memberikan dana bantuan BOSDA kepada SMK-SMK negeri yang ada di Wilayah Kota Mataram.

\section{Gebyar SMK}

Kegiatan yang dilakukan pada Gebyar SMK bertujuan untuk memamerkan hasil produk yang telah dibuat oleh siswa SMK melalui unit produksi. Kegiatan ini rutin dilakukan setiap tahun. Jad, hampir semua SMK di Kota Mataram akan disibukkan dengan kegiatan tersebut. Setiap sekolah menunjukkan kompetensi keahlian yang dimiliki serta me- 
nunjukkan apa saja yang telah dicapai dan tentunya apa saja yang telah dihasilkan, sehingga pengunjung dapat melihat hasil karya siswa-siwa SMK, bahkan bisa membeli produk-produk yang telah dibuat.

\section{Peran DUDI dalam Pengembangan SMK di Kota Mataram.}

\section{Peyelenggaraan Prakerin SMK}

Penyelenggaraan prakerin siswa wajib diadakan setiap tahunnya. Pada saat prakerin siswa dititipkan untuk belajar di DUDI yang telah berkerja sama dengan sekolah. Prakerin memiliki banyak manfaat terhadap peningkatan kompetensi keahlian siswa, karena pada saat prakerin siswa lebih banyak dihadapkan pada praktik daripada teori. Setelah mengikuti prakerin, siswa lebih menguasai kompetensi keahlian yang ditekuni. Selain itu, prakerin dapat menumbuhkan minat siswa untuk berwirausaha. Saat melaksanakan pra-kerin, tentunya ada pembimbing prakerin dari pihak industri, yang membimbing siswa selama berada di industri. Kerja sama lain yang dilasanakan antarsekolah dengan DUDI selain prakerin adalah uji kompetensi siswa untuk siswa kelas 3. Dalam hal ini, perwakilan dari DUDI diminta untuk menguji siswa dalam uji kompetensi keahlian siswa.

\section{Peran Pembinaan Guru}

Peran pembinaan guru dalam bentuk magang guru. Kerja sama terkait magang guru yang dilaksanakan dengan DUDI bertujuan untuk meningkatkan pengetahuan ilmu dan keterampilan guru, khususnya guru produktif.

\section{Peran Pembinaan Siswa}

Selain Prakerin dan uji kompetensi keahlian pada siswa. Kaitannya dengan keterlibatan DUDI terhadap siswa adalah sebagai tempat penyaluran lulusan.

\section{Peran Penyediaan Sarana dan Prasarana}

Lingkup keterlibatan DUDI dalam hal penyediaan saran dan prasarana dinilai masih kurang. Hal ini berbeda dengan kompetensi keahlian teknik otomotif atau teknik sepeda motor, yang industri sendiri yang menawarkan ke sekolah untuk diberikan saran dan prasaran pendukung belajar, seperti pembukaan bengkel. Akan tetapi sekolah terus melakukan upaya kerja sama dengan industri terkait sarana dan prasarana tersebut.

\section{Peran Pengembangan Kurikulum}

Pengembangan kurikulum dilakukan dalam bentuk workshop kurikulum. Dalam pengembangan kurikulum sekolah ditentukan kompetensi seperti apa yang dibutuhkan oleh industri yang akan diajarkan pada siswa. Untuk mencapai relevansi dengan kebutuhan dunia kerja maka diperlukan keterlibatan industri pasangan.

\section{SIMPULAN DAN SARAN}

\section{Simpulan}

Peran DUDI dalam mendorong kebijakan Pemerintah Daerah terkait pengembangan SMK berbasis kearifan lokal di Kota Mataram belum memadai. Sampai dengan saat ini, belum ada kebijakan dalam bentuk program atau peraturan yang dilaksanakan antara Pemda dengan industri terkait penyelenggaraan SMK yang berbasis kearifan lokal. Akan tetapi, Pemda telah membuka kompetensi keahlian yang disesuaikan dengan keunggulan daerah. Antara lain: bidang kerajinan EMP, pada SMKN 5 Mataram dengan kompetensi keahlian kria Logam. Kompetensi keahlian agribisnis ternak ruminansia, agribisnis tanaman hortikultura dan teknik perikanan. Untuk mendorong program pijar (sapi, jagung dan rumput laut).

Impelementasi penyelenggaraan SMK yang ada di Kota Mataram, dapat dilihat dari beberapa program yang dilakukan Pemda, dalam hal ini Dinas Dikpora Kota Mataram, antara lain: (1) monitoring dan Evaluasi, (2) Menyediakan Unit Gedung Baru (UGB), (3) Pembukaan Program Baru atau Kompetensi Keahlian Baru, (4) Bantuan Dana BOS dan BOSDA, serta (5) Mengadakan Gebyar SMK se-Kota Mataram yang dilaksanakan setiap tahun.

Peran DUDI dalam pengembangan SMK di Kota Mataram antara lain: (a) dalam hal penyelenggaraan prakerin, sejauh ini berjalan dengan baik. penyaluran prakerin siswa rutin dilaksanakan setiap tahunnya selama 2-3 bulan; b) industri sebagai tempat pemagangan guru, untuk meningkatkan keterampilan guru produktif; (c) pihak industri terlibat dalam uji kompetensi siswa tingkat akhir dan sebagai 
tempat menyalurkan lulusan; (d) terkait penyediaan sarana dan prasarana belum ada kerja sama yang dilakukan; (e) pengembangan kurikulum telah melibatkan industri dalam bentuk workshop kurikulum.

\section{Implikasi}

Dalam penyelenggaraan SMK yang berbasis kearifan/keunggulan lokal, pada penelitian ini memang belum ada perhatian yang khusus pada SMK 5 Mataram (kria) dan SMK PP N Mataram yang berbasiskan unggulan lokal. Pemda dalam hal ini Dinas Dikpora seharusnya lebih mendukung SMK yang berbasiskan unggulan lokal tersebut, harapannya lulusan dari pendidikan kejuruan tersebut memiliki kemampuan relevan dengan kebutuhan daerahnya.

Program yang dicangangkan oleh Pemda haruslah melibatkan DUDI, karena program yang dilaksanakan kurang melibatkan pihak DUDI terutama industri yang merupakan potensi daerah. Pelibatan industri dalam program-program penyelenggaraan SMK dimanfaakan seoptimal mungkin. Untuk menunjang pendidikan agar dapat lebih maju, kerja sama dilakukan baik dalam monitoring dan evaluasi, ataupun program lainnya.

Kerja sama yang dilakukan antara industri dengan sekolah dalam hal prakerin, telah berkontribusi banyak terhadap peningkatan kompetensi keahlian siswa. Kurikulum yang telah diajarkan disekolah dapat diterapkan bahkan dapat dikembangkan di industri/ perusahaan tempat mereka prakerin. Hal ini karena materi pelajaran yang telah diajarkan hampir sama dengan apa yang sedang dikerjakan di industri hanya saja siswa merasakan kurangnya praktik yang didapatkan di sekolah.

\section{Saran}

Perlu adanya kebijakan terhadap SMK yang berbasis kearifan lokal tersebut, Hal ini diharapkan adanya koordinasi untuk menyamakan persepsi antarpihak terkait dan mendorong terciptanya komitmen bersama dalam pengembangan SMK berbasis kearifan lokal. Pemerintah, industri lokal dan SMK yang menyelenggarakan kompetensi kehalian yang berbasis kearifan lokal.

Mendorong terciptanya komitmen dunia usaha untuk ikut berpartisipasi aktif dalam pengembangan SMK berbasis kearifan lokal, dalam penentuan kompetensi bidang keahlian yang akan dikembangkan, penyusunan muatan kurikulum, sharing pembiayaan pembangunan dan bantuan kerja sama dalam penyediaan sarana dan prasarana selama proses pembelajaran.

Sekolah melalui Wakasek Humas Industri perlu membenahi dalam hal kerja sama dengan industri. Sekolah harus memiliki BKK dan pendataan alumni yang baik, agar dapat meningkatkan kulitas sekolah.

Pengembangan SMK berbasis kearifan lokal di Kota Mataram sangat dibutuhkan guna menyeleraskan kompetensi keahlian lulusan SMK dengan kebutuhan dunia kerja dan berusaha terkati sektor unggulan daerah.

\section{DAFTAR PUSTAKA}

Anwar. (2001). Pelaksanaan Program Pendidikan Sistem Ganda Pada SMK Di Kota Kendari. Diambil pada tanggal 20 September 2014, dari www.depdiknas.go.id/jurnal/41/Anwar. $\underline{\mathrm{html}}$.

Asmani, M.J. (2012). Pendidikan Berbasis Kearifan lokal. Jogjakarta: DIVA Press.

Depdikbud. (2006b). Bahan Bimbingan Dan Teknik Penyusunan Kurikulum Tingkat Satuan Pendidikan (KTSP) Dan Silabus Sekolah Menengah Kejuruan. Jakarta: Direktorat Pembinaan Sekolah Menengah Kejuruan.

Depdikbud. (2005). Rencana Pembangunan Jangka Panjang. Jakarta: Depdiknas.

Direktorat Pengembangan SMK. (2010). Road Map Pengembangan SMK 2010-2014.

Djojonegoro, W. (1998). Pengembangan sumber daya manusia melalui sekolah menengah kejuruan (SMK). Jakarta: PT Balai Pustaka.

Gubernur NTB. (2015). Peraturan Daerah Nomor 4 Tahun 2015, Tentang penyelenggaraan Pendidikan. Diambil pada tanggal $20 \quad$ Juni 2015 http://jdih.ntbprov.go.id/sites/default/fil es/produk_hukum/LD\%20Perda\%20No \%204\%20Th\%202015.pdf.

Sutrisno, J. (2006). Penyelenggaraan Sekolah Menengah Kejuruan. Jakarta: Direk- 
torat Pembinaan Sekolah Mengenah Kejuruan.

Muliati. (2008). Evaluasi pendidikan sistem ganda (Suatu penelitian evaluatif berdasarkan Stake's countenance model mengenai program pendidikan sistem ganda pada sebuah SMK di Sulawesi Selatan (2005/2007)). Disertasi. Tidak dipublikasikan. Universitas Negeri Jakarta.

Priyatama, A., \& Sukardi, S. (2015). Profil Kompetensi Siswa SMK Kompetensi Keahlian Teknik Kendaraan Ringan di Kota Pekalongan. Jurnal Pendidikan Vokasi, Volume 3, Nomor 2, Juni 2013, diambil pada tanggal 22 Oktober 2015, dari

http://journal.uny.ac.id/index.php/jpv/ar ticle/view/1593.

Qurratu, A. (2009). Konsep Pengembangan Sekolah Menengah Kejuruan (SMK) Berbasis Industri di Kabupaten Sidoardjo. Jurnal Penataan Ruang, diambil pada tanggal 15 Juni 2015, dari http://digilib.its.ac.id/public/ITSMaster-10252-Paper.pdf.

Sarundajang, S.H. (2001). Arus Balik Kekuasaan Pusat Ke Daerah. Jakarta: Pustaka Sinar Harapan.

Syarifuddin, A. (1991). Titik berat otonomi daerah pada Dati II dan perkembangannya. Bandung: Mandar Maju.
Republik Indonesia. (2004). Undang-Undang RI Nomor 32 Tahun 2004, Tentang Sistem Pemerintah Daerah.

Usman, A.B. (2004). Pendidikan nasional memasuki era otonomi daerah, dalam edy suadi hamid dan sobirin malian, memperkokoh otonomi daerah: kebijakan, evaluasi dan sarana. Yogyakarta: UII Press.

Pardjono. (2011). Peran industri dalam pengembangan SMK. Makalah disampaikan pada workshop peran industri dalam pengembangan SMK di SMKN 2 Kasihan Bantul.

Tim Penyelaras Pendidikan Dengan Dunia Kerja. (2010). Perancangan model konseptual pengukuran kinerja penyelarasan pendidikan dengan dunia kerja. Jakarta: Tim Penyelaras Pendidikan Dengan Dunia Kerja.

Wagiran. (29 April - 2 Meri 2010). Pengembangan pendidikan kejuruan berbasis potensi daerah dan sumber daya alam dalam mendukung continuing vocational education. Makalah disajikan dalam Seminar Aptekindo di Universitas Pendidikan Denpasar.

Wayong, J. (1979). Asas dan tujuan pemerintah daerah. Jakarta: Penerbit Djambatan. 